\title{
PRAGMATISME KOMUNIKASI MASYARAKAT PEDESAAN (Rekonstruksi Ruang Sosial Penggunaan Telepon Seluler di Pedesaan)
}

\author{
Oleh: Abdul Halik ${ }^{1}$ \\ Dosen Fakultas Dakwah dan Komunikasi \\ UIN Alauddin Makassar \\ E-mail: kacomandar@yahoo.co.id
}

\begin{abstract}
The use of mobile phone in interpersonal communication is not only used by urban society, but also by rural society. The structure of social, culture, and norms which are clasically owned by the rural society has been displaced. The rural society construct their values and social communication act as the concequence of the use of mobile phone massively.

The change of the rural society production activity has direclty boosted the social space. The pattern of social interaction is used to be collective, but now to be individual. The elements which are developed social interaction in rural area are moving dinamically and able to reproduce social values such as individualistic, effectivity, and pragmatism.
\end{abstract}

Key words: Rural Society, Social Space, Social Interaction, Mobile Phone

\begin{abstract}
ABSTRAK
Penggunaan telepon seluler dalam komunikasi antarmanusia tidak saja dipraktikkan oleh masyarakat kota, tetapi juga di kalangan masyarakat pedesaan. Struktur sosial, budaya, dan norma-norma yang secara klasik dimiliki masyarakat desa dalam interaksi sosial, kini mengalami pergeseran. Masyarakat pedesaan merekonstruksi nilai-nilai dan praktik komunikasi sosial mereka sebagai konsekuensi dari penggunaan telepon seluler secara massif.

Perubahan aktivitas produktif masyarakat pedesaan juga secara tidak langsung mendorong bergesernya ruang-ruang sosial. Pola interaksi sosial yang awalnya bersifat kolektif cenderung menjadi lebih individual. Unsur-unsur yang membangun interaksi sosial di pedesaan bergerak dinamis dan memungkinkan reproduksi nilai-nilai sosial baru seperti individualistis, efektivitas, dan pragmatisme.
\end{abstract}

Kata kunci: Masyarakat pedesaan, ruang sosial, interaksi sosial, telepon seluler.

\footnotetext{
${ }^{1}$ Dr. Abdul Halik, S.Sos., M.Si., Dosen tetap pada Jurusan Ilmu Komunikasi Fakutas Dakwah dan Komunikasi dan Program Pascasarjana UIN Alauddin Makassar
} 


\section{A. Pendahuluan}

Ruang sosial menjadi arena interaksi di antara anggota kelompok atau komunitas tertentu. Ruang sosial yang dimaksud dalam studi ini tidak dibatasi pada unsur fisik (tempat) saja, tetapi lebih merupakan wadah berlangsungnya hubungan-hubungan sosial yang intensif (non-fisik). Seorang anggota kelompok membangun relasi dengan anggota kelompok lainnya dalam ikatan yang ditandai oleh makna-makna dan tujuan-tujuan tertentu. Makna-makna tersebut dikonstruksi oleh mereka sebagai hasil kesepakatan yang tidak diformalkan secara institusional. Mereka membentuk kesepakatan-kesepakatan sosial dengan format dan kualitas yang disusun secara cair. Hal ini mendorong fleksibilitas norma dan prinsip dari relasi yang mereka bangun, meskipun dengan tujuan pemenuhan kebutuhan real mereka.

Hubungan sosial yang intensif akan mendorong terbentuknya keutuhan sosial yang lebih kuat. Dalam konteks masyarakat pedesaan, keutuhan tersebut lebih menyiratkan kebersamaan, gotong-royong, dan kolektivitas. Nilai-nilai tersebut dewasa ini tampak mengalami pergeseran oleh berbagai faktor pendorong, seperti pendidikan, ekonomi, teknologi, dsb. Dalam hal penggunaan instrumen teknologi komunikasi, misalnya penggunaan telepon seluler secara massif di pedesaan, telah membawa warna dan pola baru bagi aktivitas relasional di masyarakat pedesaan. Hal ini antara lain terjadi pada pola komunikasi antarpersona yang sebelumnya mendasari prinsip keutuhan sosial di pedesaan.

Kecenderungan bergesernya pola komunikasi tersebut berimplikasi bagi berbagai sektor kehidupan masyarakat desa, seperti aktivitas ekonomi, budaya, sosial, pendidikan, dan keagamaan. Penggunaan telepon seluler secara meyakinkan telah membawa peningkatan kuantitas, intensitas, dan ekstensitas hubungan sosial. Hal ini menjadi modal sosial yang penting jika dipraktikkan secara sehat dan produktif. Frekuensi dan volume pembicaaraan yang relatif terbatas jika dilakukan secara face to face mendorong munculnya rasa bosan berinteraksi. Hal ini juga terkait dengan relatif terbatasnya mitra komunikasi di pedesaan. Berkomunikasi secara tatap muka dengan "orang yang itu-itu juga" membuat masyarakat desa cenderung merasa bosan, meskipun di sisi lain 
dianggap cukup menyenangkan. Komunikasi antarpersona dan kelompok dengan cara klasik, secara konseptual mensyaratkan terjadinya pertemuan tatap muka agar mereka bisa saling mengontrol secara langsung, baik yang berdimensi pesan verbal maupun melalui pesan-pesan non-verbal. Pola komunikasi seperti itu telah dipraktikkan di pedesaan sejak lama, dan tidak ada masalah yang berarti. Namun rasa bosan tersebut muncul justru setelah mereka mengenal bentuk interaksi lain yang dianggap lebih efektif, kekotaan, maju, dan terpelajar.

Penggunaan telepon seluler di pedesaan cenderung memberi reputasi tersendiri dalam konteks pendidikan. Terdapat asumsi bahwa yang memegang dan menggunakan telepon seluler tergolong masyarakat terpelajar, yakni sedang atau pernah mengikuti pendidikan formal tertentu. Bahkan penggunaan telepon seluler dianggap dapat menutupi kekurangan secara personal, misalnya label pendidikan. Kecenderungan ini menunjukkan terjadinya praktik dramaturgis dalam interaksi sosial yang nyata di masyarakat pedesaan. Kompetisi sosial yang pada awalnya kurang diperhatikan dalam masyarakat pedesaan, kini telah menjadi bagian penting dalam kehidupan masyarakat desa. Kompetisi personal tersebut antara lain menuntut bergesernya prestise sosial, dari hal-hal yang berkaitan dengan status sosial, keturunan atau asal-muasal, dan riwayat ekonomi kepada hal-hal yang lebih bersifat pencapaian prestasi. Faktor pemicu lainnya adalah semakin banyaknya warga desa yang menempuh pendidikan formal sampai perguruan tinggi.

\section{B. Konstruksi Identitas Sosial Pengguna Telepon Seluler di Pedesaan}

Penggunaan telepon seluler yang meluas pada akses internet di pedesaan, secara umum membawa pemahaman dan sikap personal baru dalam berbagai konteks. Misalnya dal hal memaknai kebebasan, politik, demokrasi, kehidupan bernegara, dan seterusnya. Dalam konteks masyarakat pedesaan, mereka memanfaatkan ruang sosial untuk mempererat ikatan persaudaraan, sehingga ruang sosial memiliki makna yang cukup penting, tidak sekedar tempat bercengkrama. Ruang sosial tersebut juga sarana yang dapat memproduksi sikap 
saling percaya, mengkonstruksi norma sosial, dan mendorong keutuhan dalam masyarakat.

Penggunaan telepon seluler dalam berkomunikasi, pada skala mikro juga memproduksi makna lain di luar dari esensi lambang bahasa yang digunakan. Kesan penggunaan telepon seluler di pedesaan lebih bernilai dari sisi ekonomis, kelas sosial atau prestise pribadi, nilai keterpelajaran, dan jangkauan relasi sosial. Hal ini tampak pada kecenderungan penggunaan telepon seluler yang dikonstruksi lebih 'pantas' menggunakan bahasa Indonesia daripada bahasa daerah. Padahal dalam interaksi sehari-hari mereka secara face to face, tetap saja menggunakan bahasa daerah.

Konstruksi seperti ini didorong oleh pemaknaan kolektif dari pengguna telepon seluler di desa bahwa dibutuhkan penyesuaian-penyesuaian tertentu dalam bekomunikasi atau berinteraksi melalui telepon seluler. Penyesuaian-penyesuaian tersebut antara lain berdimensi skill, starata sosial, dan pola aktivitas sehari-hari.

Menurut Mead, individu merupakan makhluk yang sensitif dan aktif. Keberadaan sosialnya memengaruhi bentuk lingkungannya (secara sosial maupun dengan dirinya sendiri) secara efektif, sebagaimana lingkungan memengaruhi kondisi sensitivitas dan aktivitasnya (Salim, 2008: 31). Dengan demikian lingkungan dipandang dapat membentuk masyarakat sebagaimana masyarakat juga membentuk lingkungan.

Blumer (1969) menyatakan bahwa individu berperilaku berdasarkan makna yang berasal dari interaksi sosial. Makna-makna individu tersebut merupakan produk interaksi yang melibatkan aktor sosial yang sadar eksistensi. Makna senantiasa dimodifikasi melalui proses interpretasi secara kontinyu oleh individu yang berpartisipasi dalam interaksi (Outhwaite, 2008: 398). Dengan demikian, berangkat dari prinsip teori interaksi simbolis ini, perilaku interaksional dari seseorang dapat dipahami hanya berdasarkan tindakan interpretasi resiprokal dalam konteks situasional, historis, dan kultural tertentu.

Pembicaraan biasa sebagai interaksi antarpersona dalam lingkungan masyarakat desa tampak mengalami perluasan topik, keragaman cara pandang, volume, dan intensitas yang relatif meningkat. Meskipun disadari oleh 
penggunanya, pemakaian telepon seluler dalam komunikasi antarpersona membutuhkan pengorbanan ekonomis tertentu dan bersifat "sangat kuat godaannya". Masyarakat desa menilai bahwa komunikasi melalui telepon seluler merupakan sesuatu yang awalnya mencitrakan nilai prestisius, maju, membanggakan, dan praktis, kini telah dianggap hal yang biasa-biasa saja.

Kehidupan sosial terjalin dalam iterrelasi yang saling memengaruhi. Struktur sosial tidak saja membedakan secara hirarki bagi karakteristik dan perilaku yang berbeda dari pendukung komunitas tertentu, tetapi juga menunjukkan hidup bersosial membutuhkan kreativitas. Dalam konteks kesalinghubungan inilah manusia merumuskan pola-pola yang berulang dari tindakan mereka dalam performa sosialnya. Manusia mengkonstruksi nilai-nilai yang dianggapnya relevan dengan warisan sosial serta penanda bagi komunitas. Rasio mengatur dan mengendalikan segala macam aspek kehidupan manusia yang berhubungan dengan dirinya sendiri, maupun yang dikaitkan dengan entitas di luar dirinya.

\section{Pemahaman Berinteraksi Sosial melalui Telepon Seluler di Pedesaan}

Hubungan persaudaraan masyarakat desa yang dikenal hangat dan dekat, dewasa ini mengalami tantangan yang cukup berat. Realitas berpikir sendiri, bersikap sendiri, dan cenderung berperilaku sendiri telah mereduksi sifat kolektivitas yang menjadi ciri utama masyarakat desa. Meskipun berinteraksi melalui SMS atau kontak langsung (berbicara) dengan telepon seluler tetap bisa menjaga kebersamaan dan persaudaraan, namun pola ini sedikit demi sedikit mengurangi nilai-nilai kedekatan di atara mereka. Secara umum, di kalangan masyarakat pedesaan telah terjadi pergeseran pola mata pencaharian. Pergeseran aktivitas produktif seperti ini, dengan sendirinya juga merekonstruksi ruang-ruang sosial di kalangan mereka sebagai masyarakat desa. Perbincangan yang hangat, gosip atau diskusi mengenai hal-hal pribadi atau pekerjaan, dewasa ini cenderung lebih banyak dilakukan melalui penggunaan telepon seluler. 
Dalam konteks perspektif interaksionisme simbolis, berkomunikasi menggunakan telepon seluler di kalangan masyarakat desa dimaknai sebagai sesuatu yang memudahkan dan merupakan tuntutan perkembangan zaman. Pemaknaan ini diterjemahkan dalam tindakan mereka pada proses sosialisasi melalui interaksi dengan penyesuaian-penyesuaian individu dalam lingkungan sosialnya. Menghadapi penggunaan teknologi komunikasi yang massif di masyarakat atau di lingkungan mereka, masyarakat desa menilai bahwa mereka harus bisa bertindak dan menyesuaikan diri dengan lingkungannya untuk tetap bisa eksis dan diakui sebagai warga kelompok atau masyarakatnya. Sebahagian yang lain memandang bahwa interaksi melalui penggunaan telepon seluler mendorong bangkitnya kesadaran akan pentingnya sesuatu hal untuk diperhatikan atau dilakukan, tanpa harus merasa dipengaruhi oleh lingkungan eksternal mereka. Kecenderungan ini menunjukkan bahwa hubungan antara individu dan masyarakat memang tampak saling memengaruhi dan "memproduksi" seperti yang diakui oleh Mead dan Blumer dalam konsepsi dasar interaksionisme simbolisnya.

Masyarakat telah membentuk individu sebagai sosok yang memiliki entitas sesuai atau relevan dengan lingkungannya. Di sisi lain, individu dengan kehendak bebas dan daya kreativitasnya berpotensi menjadi kreator perubahan bagi lingkungan masyarakatnya. Sifat saling membentuk dan membutuhkan ini menjadi jalinan yang relatif berimbang. Interaksi sosial secara evolutif mengevaluasi dan menyempurnakan makna-makna yang dikonstruksi masyarakat melalui tindakan komunikasi mereka.

Perspektif interaksionisme simbolik melihat setiap individu di dalam dirinya memiliki esensi kebudayan, berinteraksi di tengah sosial masyarakatnya, dan menghasilkan makna 'buah pikiran' secara kolektif (Umiarso dan Elbadiansyah, 2014: 5). Masyarakat sebagai realitas subjektif dalam pandangan konstruksi sosial menurut Patrick Berger lebih menekankan hubungan timbalbalik yang disebutnya sebagai 'hubungan dialektis' antara individu dan masyarakat, yaitu hubungan saling membentuk dan saling menentukan (Samuel, 2012: 35). Dengan demikian, makna yang dilekatkan pada individu pada sesuatu 
objek tidak bersifat permanen atau tidak melekat pada objek tersebut. Hal ini dimungkinkan bukan terutama pada kesadaran dinamika objek yang ditafsirkan, tetapi terutama pada kondisi diri subjek yang memberi makna bersangkutan. Pergeseran pemaknaan ini sering terjadi dalam kehidupan individu. Tuntutan terjalinnya hubungan yang harmonis dengan melakukan penyesuaian-penyesuain perilaku tertentu pada lingkungan eksternalnya merupakan antara lain faktor yang mendorong fleksibilitas pemaknaan pada sesuatu objek. Jika makna-makna tertentu dialamatkan pada objek-objek tertentu oleh individu, berarti dia telah mendesakkan faktor subyektifnya. Keterlibatan beberapa individu dalam interaksi sosial menuntut terjadinya modifikasi pemaknaan oleh individu manusia.

Interaksi sosial melalui penggunaan telepon seluler mengurangi intensitas tatap muka. Sementara sifat komunikasi tatap muka cenderung lebih dekat, lebih berhati-hati, tulus, dan orisinil. Berkomunikasi melalui telepon seluler berpotensi memanipulasi simbol untuk makna-makna tetentu yang dimaksudkan oleh individu. Pemanipulasian simbol tersebut secara potensial juga memproduksi keragu-raguan atau ketidakpastian dalam diri partisipan komunikasi. Akibatnya, komunikasi melalui telepon seluler sering diikuti perasaan cemas dan curiga atas apa yang telah disampaikan, termasuk tafsiran atau makna yang dikonstruksinya. Dengan demikian, ruang-ruang sosial makin bertambah luas jangkauannya namun secara substansional interaksi sosial cenderung mengalami gradasi.

Interaksi melalui telepon seluler juga tampak cenderung lebih berani dan kurang mempertimbangkan aspek-aspek etis dari penyampaian pesan, baik yang berkaitan dengan substansi maupun konteksnya. Misalnya untuk menyampaikan pesan tertentu pada orang lain, individu mempertimbangkan berulang-ulang untuk menyampaikannya secara langsung pada partisipan yang dimaksudkan. Namun dengan telepon seluler dianggap lebih ringan dan mudah. Format interaksi sosial seperti ini menjadikan masyarakat desa mengalami semacam lompatan budaya yang 'mengagetkan' mereka. Namun frekuensi interaksi sosial cenderung mengalami peningkatan yang cukup berarti.

Dalam berinteraksi, manusia menggunakan simbol-simbol komunikasi. Keberadaan simbol-simbol tersebut merupakan sesuatu yang sangat urgen bagi 
keberhasilan komunikasi (Nina Winangsih Syam, 2009: 30). Namun demikian, dalam konteks komunikasi antarpersona melalui telepon seluler, penggunaan simbol-simbol komunikasi menjadi terbatas. Formatnya tereduksi oleh sifat komunikasinya yang berjarak. Jika seseorang sedang berbicara dengan orang lain melalui telepon seluler, maka ia hanya bisa menerima dan memaknai simbolsimbol bahasa yang digunakannya secara leksikal meskipun juga dibarengi dengan format pesan non-verbal secara terbatas, seperti paralinguistik dan penggunaan waktu jeda dalam pembicaraan. Seseorang yang berbicara melalui telepon seluler cenderung terfokus hanya pada apa yang mereka bicarakan secara substansi bahasa saja. Berbeda dengan saat berbicara secara tatap muka yang dapat menggunakan simbol-simbol komunikasi secara lebih lengkap, seperti air muka, gerakan mata, gerakan bibir, kedekatan, konteks ruang dan waktu, dan lainnya. Semakin beragam format pesan komunikasi yang digunakan atau dilibatkan penggunanya semakin detail dalam memaknai maksud pesan yang mereka pertukarakan. Terkonsentrasinya perhatian pada pemaknaan denotatif pada simbol bahasa juga berkonsekuensi bagi ekspresi emosional partisipan komunikasi.

Keterbatasan dukungan simbol-simbol non-verbal bagi partisipan komunikasi dalam interaksi melalui telepon seluler menunjukkan format pesan komunikasi cenderung mengecil. Kecenderungan ini mengindikasikan perubahan format dan struktur relasi dalam institusi sosial. Perubahan ini juga menunjukkan dinamika tindakan sosial yang mencerminkan dinamika aktor sosialnya. Dalam pandangan Blumer, institusi sosial mengalami perubahan bila ada perubahan dalam definisi subjektif atau pola interaksi yang menjadi dasarnya. Interaksionisme simbolis menganalisis saling ketergantungan antara kesadaran subjektif dan pola interaksi di tingkat mikro (Nina Winangsih Syam, 2009: 30).

\section{Konsekuensi Penggunaan Ponsel bagi Format dan Ruang Komunikasi Sosial Masyarakat Pedesaan}

Pergeseran nilai-nilai sosial oleh kemajuan teknologi yang dikonkritkan oleh perilaku praktis manusia, mendorong kebiasaan dan menjadi identitas 
komunitas mereka. Interaksi dan pergaulan sosial di kalangan masyarakat desa cenderung tidak lagi dikontrol oleh domain moral yang kuat. Peradaban baru telah memberi ruang yang lebih nyaman dan bebas bagi individu.

Teori konstruksi sosial lebih menekankan pada tindakan manusia sebagai aktor yang kreatif dari realitas sosialnya (Sukidin, 2002: 194). Teori ini memandang individu sebagai entitas yang bebas melakukan hubungan antarmanusia. Sebagai individu, manusia memproduksi realitas sosialnya secara kreatif. Realitas dilihat sebagai produk dari kreativitas manusia. Weber melihat realitas sosial sebagai perilaku sosial yang memiliki makna subjektif. Hal ini mengindikasikan bahwa setiap tindakan sosial memiliki tujuan dan motivasi.

Berger dan Luckmann mengidentifikasi tiga macam realitas sosial, yakni realitas objektif, simbolik, dan subyektif. Realitas obyektif terbentuk dari pengalaman di dunia obyektif yang berada di luar diri individu. Realita obyektif dianggap sebagai suatu kenyataan. Realitas simbolik merupakan ekspresi simbolik dari realitas obyektif. Realitas subyektif adalah realitas yang terbentuk sebagai proses penyerapan kembali realitas obyektif dan realitas simbolik ke dalam individu melalui proses internalisasi (Sukidin, 2002: 195).

Untuk menghubungkan antara yang subyektif dan obyektif, Berger mengemukakan konsep dialektika yang dikenal sebagai eksternalisasi, obyektivasi, dan internalisasi. Eksternalisasi merujuk pada penyesuaian diri dengan dunia-kultual sebagai produk manusia. Obyektivasi berkaitan dengan interaksi sosial dalam dunia intersubyektif yang dilembagakan atau mengalami proses institusionalisasi. Internalisasi dilakukan saat individu mengidentifikasi diri di tengah lembaga-lembaga sosial atau organisasi sosial di mana individu menjadi anggotanya (Sukidin, 2002: 195).

Manusia adalah organisme yang sadar akan dirinya. Manusia tidak hanya semata-mata merespon stimulus yang datang dari luar dirinya. Dapat memandang dirinya sebagai obyek dan berinteraksi dengan dirinya sendiri. Manusia dapat mempertimbangkan, menguraikan, mempersoalkan, dan memberi nilai-nilai tertentu pada perilakunya dengan kesadaran yang dimilikinya. Manusia mampu merencanakan dan mengorganisasikan perilakunya. Manusia sendirilah yang 
mengkonstruksi perbuatannya, tidak semata-mata merupakan reaksi biologis, terhadap kebutuhannya, norma kelompoknya atau situasi yang melingkupinya. Orang merangkaikan suatu tindakannya dengan tindakan orang lain. Tindakan masing-masing individu menyesuaikan diri dan membentuk tindakan bersama. Tindakan bersama merupakan kegiatan kolektif yang timbul dari penyesuaian dan penyerasian perbutan orang-orang satu sama lain. Tindakan bersama terjadi dalam struktur relasi yang dinamis dan sedang berlangsung.

Perspektif interaksionisme simbolik melihat setiap individu di dalam dirinya memiliki esensi kebudayan, berinteraksi di tengah sosial masyarakatnya, dan menghasilkan makna 'buah pikiran' secara kolektif (Umiarso dan Elbadiansyah, 2014: 5). Masyarakat sebagai realitas subjektif dalam pandangan konstruksi sosial menurut Patrick Berger lebih menekankan hubungan timbal balik yang sebutnya sebagai 'hubungan dialektis' antara individu dan masyarakat, yaitu hubungan saling membentuk dan saling menentukan (Samuel, 2012: 35).

Nilai-nilai kemuliaan budaya masyarakat desa mengalami pergeseran, seiring dengan semakin populernya gaya hidup pragmatisme. Kecenderungan individu untuk memberi perhatian pada kenikmatan hidup sesaat, sesungguhnya membuat hidupnya menjadi sempit. Hal ini mendorong individu menjadi makhluk yang hanya mementingkan diri sendiri (individualistik), cenderung simbolis, dan dramaturgis (munafik). Individu seringkali menunjukkan diri sebagai sosok yang pandai berbicara di depan orang lain, menyembunyikan kelemahan dan kerendahannya sendiri, untuk menciptakan kesan baik. Kesan baik itu, tidak jarang dijadikan modal untuk mengulangi dan mengulangi lagi hal yang sudah disesali sebelumnya.

Persoalan pragmatisme kehidupan manusia dewasa ini tampak pada kecenderungannya yang hanya diarahkan pada dua hal saja, yakni mengumpulkan materi sebanyak mungkin dan kemudian menghabiskannya sepuasnya. Dalam konsepsi etika, ini bukan masalah dinamika sosial, tetapi masalah kurangnya, atau tidak adanya kesadaran untuk hidup bersama dengan tingkat kesenangan yang lebih adil dan serasi. Jauh di pelosok desa, di daerah yang dunia material 
kehidupan menjauh, ratusan ribu individu hidup dengan kemiskinan dan tingkat pendidikan yang sangat rendah.

Menurut Mead, terdapat empat basis dan tahap tindakan yang saling berhubungan secara dialektis, yakni impuls, persepsi, manipulasi, dan konsumasi (Ritzer, 2004: 274-276) dalam (Salim, 2008: 27-28). Impulse merupakan dorongan hati yang meliputi stimulasi spontan yang berhubungan dengan alat indera dan reaksi aktor terhadap rangsangan. Manusia mempertimbangkan banyak hal setelah memperoleh rangsangan dari luar dirinya, seperti pengalaman, kesempatan, dan pertimbangan lainnya yang bersifat individual. Manusia tidak bereaksi secara spontan seperti saat binatang menerima rangsangan. Artinya manusia menggunakan akal pikirannya sebelum menanggapi rangsangan yang diterimanya.

Perspesi terjadi ketika aktor sosial mengadakan penyelidikan dan bereaksi terhadap rangsangan yang berhubungan dengan impuls. Manusia memiliki kemampuan dan kapasitas untuk merasakan dan memahami stimuli melalui perangkat alat indera yang dimilikinya. Aktor sosial menggunakan pikirannya untuk memilah dan memilih rangsangan yang akan diperhatikannya atau diabaikan. Kecenderungan pemilahan dan pemilihan rangsangan tersebut bersifat subyektif bagi setiap individu.

Setelah impuls menyatakan dirinya sendiri dan obyek telah dipahami, individu memanipulasi objek atau mengambil tindakan berkenaan dengan objek tersebut. Proses manipulasi ini mencakup pengalaman pada masa lampau, kemampuan menimbang, menekan emosi, dan lain-lain. Konsumasi merupakan proses berdasarkan pertimbangan. Aktor sosial mungkin akan memutuskan untuk bertindak melaksanakan, atau sedang pada tahap pelaksanaan atau mengambil tindakan yang memuaskan dorongan hati yang sebenarnya.

\section{E. Penutup}

Penggunaan telepon seluler dalam interaksi sosial di desa membawa pemahaman dan sikap personal yang baru dalam berbagai konteks. Masyarakat desa memanfaatkan ruang sosial untuk mempererat ikatan persaudaraan. Ruang 
sosial tersebut memiliki makna yang cukup penting bagi mereka tidak sekedar tempat bercengkrama dengan berbagai interaksi di dalamnya. Ruang sosial tersebut juga dimanfaatkan sebagai sarana yang dapat memproduksi sikap saling percaya, mengkonstruksi norma sosial, dan mendorong keutuhan dalam masyarakat. Aktivitas saling menyapa dalam ruang-ruang sosial seperti dalam aktivitas produktif, kegiatan sosial-keagamaan, aktivitas olahraga, ruang hiburan, atau keluarga, kini, dalam kuantitas dan kualitas tertentu diformat ulang oleh penggunaan telepon seluler.

Pergeseran aktivitas produktif pada masyarakat pedesaan merekonstruksi format ruang-ruang sosial sebagai masyarakat desa. Perbincangan yang hangat, gosip atau diskusi mengenai hal-hal pribadi atau pekerjaan, dewasa ini cenderung lebih banyak dilakukan melalui penggunaan telepon seluler. Seiring dengan perubahan pekerjaan, ruang-ruang sosial mengalami pergeseran yang berkonsekuensi terbentuknya pola interaksi yang bersifat individual. Nilai-niai dan praktik kolektivitas kurang terasa dan mengalami reduksi. Nilai-nilai kemuliaan budaya masyarakat desa juga cenderung mengalami pergeseran, seiring dengan semakin populernya gaya hidup pragmatisme. Kecenderungan ini mendorong masyarakat desa menjadi hanya mementingkan diri sendiri (individualistik), cenderung simbolis, dan dramaturgis.***

\section{Daftar Pustaka}

Berger, Charles, dkk. 2014. Handbook Ilmu Komunikasi (Terjemahan Derta Sri Widowatie). Bandung: Nusa Media.

Bungin, Burhan. 2006. Sosiologi Komunikasi: Teori, Paradigma, dan Diskursus Teknologi Komunikasi di Masyarakat. Jakarta Kencana.

Elbadiansyah dan Umiarso. 2014. Interaksionisme Simbolik: Dari Era Klasik Hingga Modern. Jakarta: Rajawali Pers.

Giddens, Anthony. 2010. Metode Sosiologi: Kaidah-kaidah Baru. Yogyakarta: Pustaka Pelajar.

IB. Wirawan. Teori-teori Sosial dalam Tiga Paradigma: Fakta Sosial, Definisi Sosial, dan Perilaku Sosial. Jakarta: Kencana. 2012: 94-105).

Littlejohn, Stephen W. and Karen A. Foss. 2008. Theories of Human Communication, Ninth Edition. Belmont, USA: Thomson Wadsworth.

Peter L. Berger dan Thomas Lukmann. 2012. Tafsir Sosial Atas Kenyataan (Terjemahan Hasan Basari). Jakarta: LP3ES 
Poloma, Margaret M. 2007. Sosiologi Kontemporer (Terjemahan Yasogama) Jakarta: Rajawali Pers.

Ritzer, George dan Douglas J. Goodman. 2004. Teori Sosiologi Modern (Terjemahan Alimandan). Jakarta: Kencana.

Salim, Agus. 2008. Pengantar Sosiologi Mikro.Yogyakarta: Pustaka Pelajar.

Soeprapto, Riyadi. 2002. Interaksionisme Simbolik: Perspektif Sosiologi Modern. Yogyakarta: Pustaka Pelajar.

Sukidin, Basrowi. 2002. Metode Penelitian Kualitatif Perspektif Mikro. Surabaya: Insan Cendekia.

Syam, Nina Winangsih. 2009. Sosiologi Komunikasi. Bandung: Humaniora.

Sztompka, Piotr. 2008. Sosiologi Perubahan Sosial (Terjemahan Alimandan). Jakarta: Prenada

Umiarso dan Elbadiansyah. 2014. Interaksionisme Simbolik dari Era Klasik hingga Modern. Jakarta: RajaGrafindo Perkasa. 